\title{
Inelastic Lateral-Torsional Buckling Strength of Steel I-Beams under Non-Uniform Temperature Conditions
}

\author{
Nguyen, Xuan Tung*, Alolod, Shane**, and Park, Jong Sup ${ }^{* * *}$
}

\begin{abstract}
This study assessed the inelastic lateral-torsional buckling behavior of steel I-beams under elevated temperatures. Numerical simulations were conducted using the finite element program ABAQUS. The beam models were subjected to uniform bending and varying temperature loads from a normal temperature of $20{ }^{\circ} \mathrm{C}$ to an elevated temperature of $600{ }^{\circ} \mathrm{C}$. These thermal loads were applied at the compression flange, tension flange, half of the beam, and throughout the entire beam. The combined effects of residual stress and geometric imperfection on the inelastic buckling strengths of the beams were also considered. The results showed that the scenario in which the entire beam was heated demonstrated the highest strength degradation. In addition, the compression flange of the beam was observed to be critical; thus, the local buckling of the compression flange greatly contributed to the decrease in the buckling strength compared with the other cases.
\end{abstract}

Key words : Flexural Strength, Inelastic Buckling, Elevated Temperature, Numerical Analysis

\section{요 지}

본 연구는 온도변화 영향을 받는 I형보의 비탄성 횡-비틀림좌굴거동 특성을 평가분석하고 있다. 유한요소해석 프로그램 $\mathrm{ABAQUS}$ 를 해석연구에 사용하였으며, I형보에 균일모멘트를 하중으로 작용하고, 온도영향은 표준온도인 $20^{\circ} \mathrm{C}$ 에서 고온인 $600^{\circ} \mathrm{C}$ 까지 고려하였다. 비선형좌굴해석을 위해 잔류응력과 기하비선형의 초기변형을 고려하였다. 해석결과로부터 보 전체에 온도영향을 반영한 경우에 강도감소가 가장 크게 발생하였으며, 인장부재보다는 압축부재에 온도영향을 반영하였을 때 좌굴에 보다 취약한 결과를 얻을 수 있었다. 보 전체에 $600^{\circ} \mathrm{C}$ 온도하중을 반영하였을 때 $77 \%$ 의 강도감소가 발생하였으며, 인장플랜지의 $50 \%$ 범위에 $600^{\circ} \mathrm{C}$ 온도하중을 반영하였을 때 $13 \%$ 의 강도감소를 나타내었다. 국부적으로 온도영향을 받은 부분에서 국부좌굴이 발생하기 시작하며, 최종적으로 전체좌굴이 발생되는 좌굴모드 진행을 확인할 수 있었다.

핵심용어 : 휨강도, 비탄성좌굴, 온도하중, 유한요소해석

\section{Introduction}

Steel members have been widely used as structural element for horizontal and vertical structures, such as buildings and bridges, but most of them are not provided with fire protection coatings. At elevated temperature, structural steel members are more sensitive and vulnerable than other materials. This is due to high thermal conductivity and rapid degradation of strength and stiffness which lead to decrease in load carrying capacity and eventually buckling failure. In recent years, the effects of elevated temperatures on the buckling behavior of steel I-beams has been extensively studied. Real and Franssen (2001) and Real et al. (2008) studied the lateraltorsional buckling capacities of carbon and stainless steel I-beams under fire condition. Couto et al. (2016) numerically investigated the lateral-torsional buckling of steel I-beams with slender cross section under fire. Varol and Cashell (2017) numerically investigated the lateral torsional buckling

*Member, PhD Student, Department of Civil Engineering, Sangmyung University(E-mail: tungutc2@gmail.com)

**Member, Master Student, Department of Civil Engineering, Sangmyung University(E-mail: shane.alolod@gmail.com)

***Corresponding Author, Member, Professor, Department of Civil Engineering, Sangmyung University

(Tel: +82-41-550-5314, Fax: +82-41-550-5313, E-mail: jonpark@smu.ac.kr) 
behavior of laterally unrestrained high strength steel beams at ambient and elevated temperature. Beam models from these studies were simulated and analyzed using finite element softwares in which the thermal loads are applied to the whole beam. Zang et al. (2013) investigated the effects of localized fires and the temperature gradients on the lateral torsional buckling of simply supported laterally unrestrained steel beams. In which the localized fire are applied at the lower mid-portion of the beam and propagates throughout the whole member. However in actual fire scenarios, localized fire can be exposed to other parts of the steel beams, such as at the compression and tension flange, or half of the beam. The analysis of the buckling behavior of steel conducted.

Thus, this paper aims to analyze the inelastic buckling strength of simply supported laterally unrestrained steel beams with compact cross sections subjected to pure bending and elevated temperatures. The thermal loads are applied at the compression flange, tension flange, whole beam, half of the beam, half of the compression flange, and half of the tension flange. The temperature ranges from $300^{\circ} \mathrm{C}$ to $600^{\circ} \mathrm{C}$ with an interval of $100^{\circ} \mathrm{C}$.

\section{Finite Element Modeling}

A finite element program, ABAQUS (2013), was used to perform the numerical analysis of the inelastic buckling capacities of steel beams at ambient and elevated temperature.

\subsection{Development of FE Model}

The numerical study consists of two types of analyses, the heat transfer analysis for the propagation of thermal loads; and the static riks analysis for the application of uniform moment. In the heat transfer analysis, beams were modeled as 4-noded DS4 heat-transfer quadrilateral shell. While in the static riks analysis, beams were modeled as S4R shell elements.

The beam section used in the analysis was a W30x148 beam, that were obtained from the AISC manual (2011) and generally used for beam system. The cross-section of the beam is shown in Fig. 1 The beam was categorized as compact section in the AISC manual (2011) and Class 1 cross-section based on Eurocode 3 Part 1-1 (2005). The material properties at the ambient temperature were elastic modulus of $210 \mathrm{GPa}$, yield stress of $275 \mathrm{MPa}$, and a Poisson's ratio, $\mu$, of 0.3 . For this study, varying unbraced lengths of $5 \mathrm{~m}, 7 \mathrm{~m}, 9 \mathrm{~m}, 12 \mathrm{~m}, 15 \mathrm{~m}$, and $18 \mathrm{~m}$ were considered.

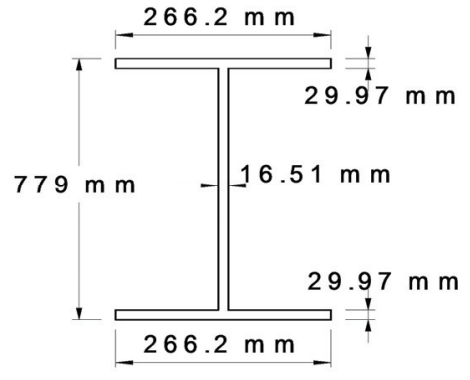

Fig. 1. W30x148 Cross Section

The mechanical load was applied at each ends of the beam and was expressed as the tension and compression forces at the bottom flange and the top flange, respectively, generating a uniform bending moment. Fig. 2 demonstrates the boundary condition of the models, in which all the beam models were simply supported. Point A was assumed to have hinge support, where the displacements at $x, y$, and $z$ directions and the rotation about the $\mathrm{x}$ axis were restrained. While point $\mathrm{B}$ was assumed to have roller support, where the displacement in directions $y, z$ and the rotation about the $\mathrm{x}$ axis are restrained. Lastly, lines $\mathrm{W}$ and $\mathrm{F}$ were restrained against $y$ and $z$ displacements, respectively.

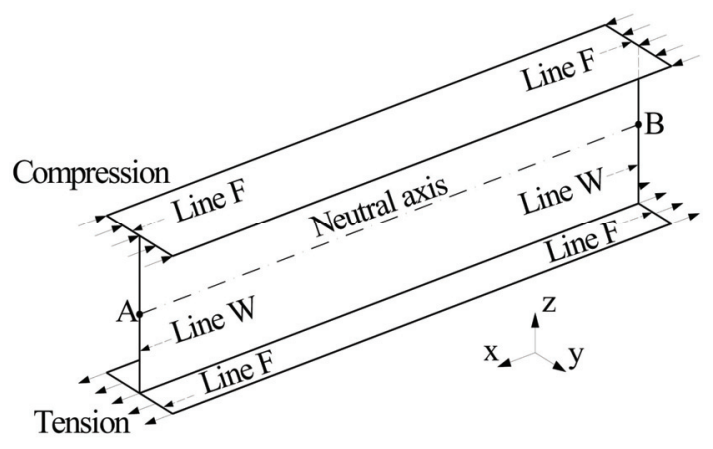

Fig. 2. Loading and Boundary Conditions

The application of thermal loads (ISO-834, 1999) were shown in Fig. 3 Beam models were divided into six types based on the temperature exposure area. They were temperature exposed over whole beam (F-WB), compression flange (F-CF), tension flange (F-TF), $50 \%$ of whole beam $(50 \% \mathrm{~F}-\mathrm{WB}), 50 \%$ of compression flange $(50 \% \mathrm{~F}-\mathrm{CF})$, and $50 \%$ of tension flange $(50 \% \mathrm{~F}-\mathrm{TF})$.

As mentioned previously, properties of steel changes when exposed to elevated temperatures. Thus, the temperaturedependent properties of steel such as thermal and mechanical properties, must be considered in the analysis.

Figs. 4(a) and (b) illustrates the variation of thermal conductivity and specific heat that were obtained from formula 

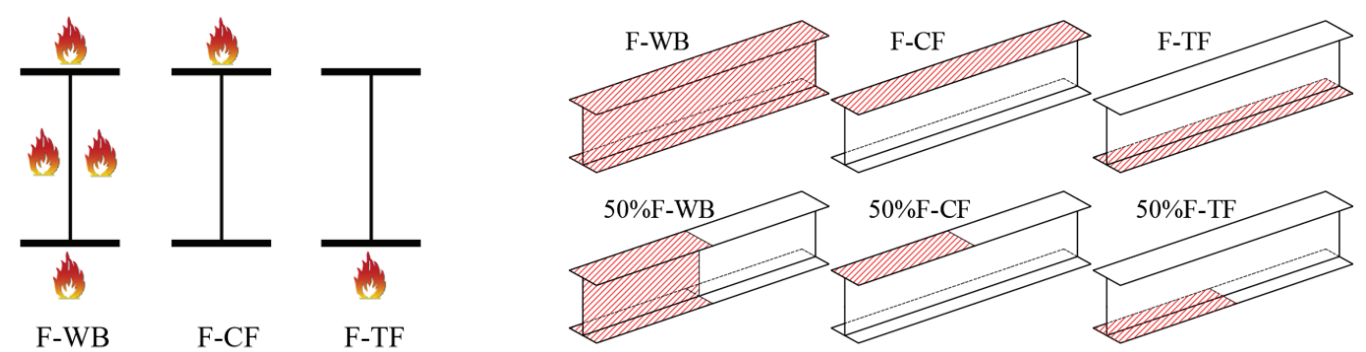

Fig. 3. Heat Transfer Boundary Conditions

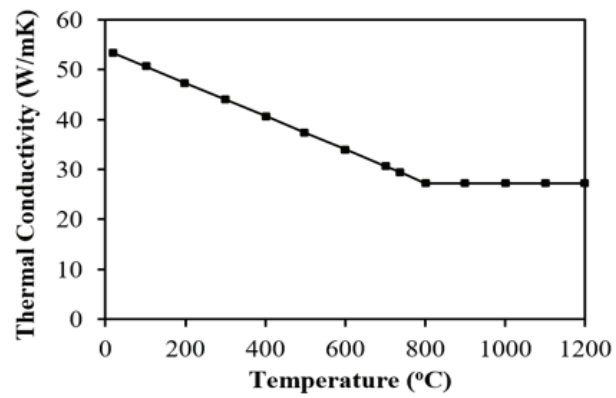

(a) Thermal conductivity of steel

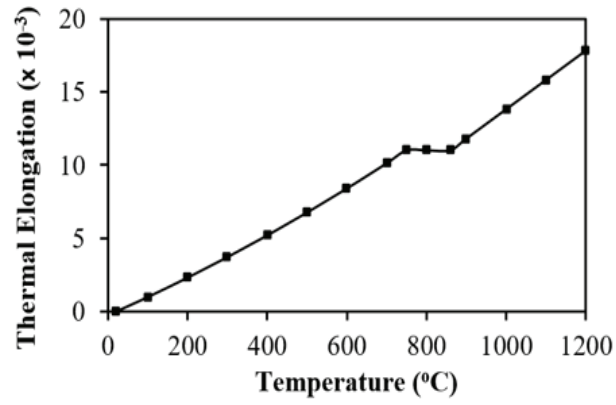

(c) Thermal elongation of steel

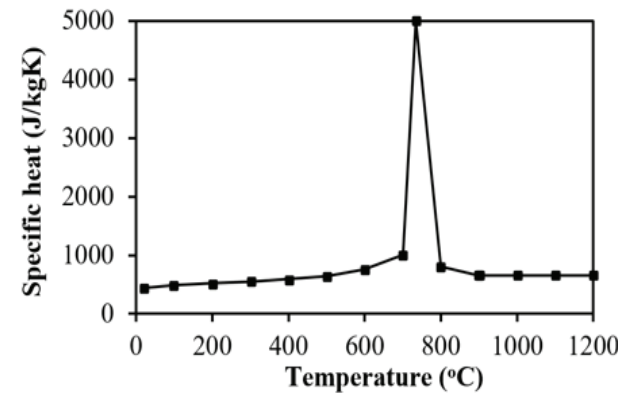

(b) Specific heat of steel

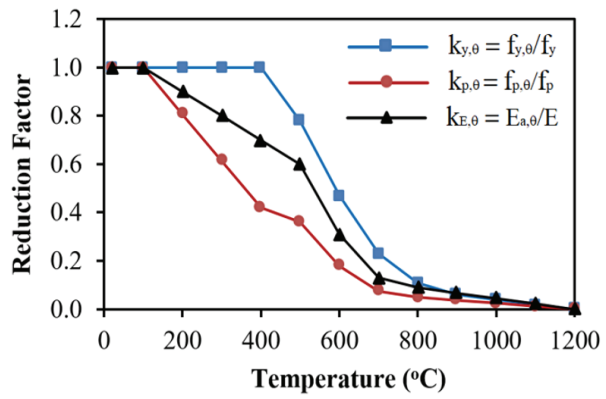

(d) Strength and stiffness reduction factor

Fig. 4. Material Properties of Steel

as given in Eurocode 3 Part 1-2 (2005). In addition, the density of steel was assumed to be $7,850 \mathrm{~kg} / \mathrm{m}^{3}$ regardless of the temperature.

The mechanical properties of steel includes the elongation coefficient, the yield strength, Young's modulus and stressstrain relationship. The elongation coefficient was described in Eurocode 3 Part 1-2 (2005) as shown in Fig. 4(c) Reduction factors were employed to depict the degradation of the proportional limit $\left(k_{p, \theta}=f_{p, \theta} \theta f_{p}\right)$, yield strength $\left(k_{y, \theta}=f_{y,} \theta f_{y}\right)$ and Young's modulus $\left(k_{E, \theta}=E_{a, \theta} E\right)$ at elevated temperature, as shown in Fig. 4(d) In this figure, $f_{p, \theta} f_{y, \theta}$ and $E_{a, \theta}$ represent the proportional limit, effective yield strength and slope of the linear elastic range, at a temperature $\theta$, respectively. Lastly, Fig. 5 shows the stress-strain curve at elevated temperature for hot rolled steel taken from Eurocode 3 Part 1-2 (2005).

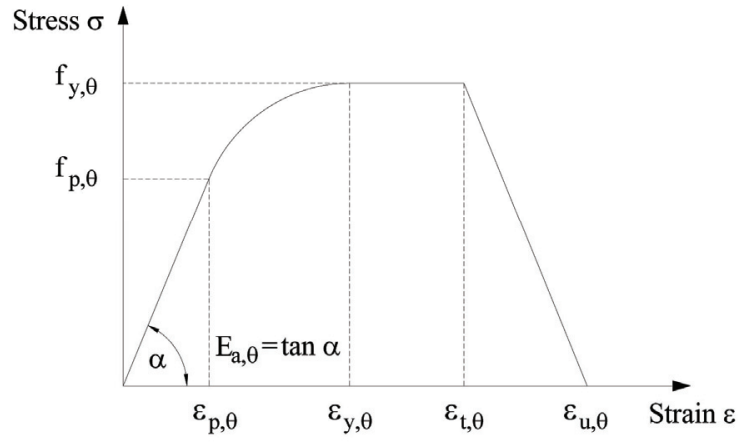

Fig. 5. Stress-strain Curve at Elevated Temperature

Initial imperfections of residual stress and geometric imperfection were introduced to the numerical models as illustrated in Fig. 6 The residual stress followed the pattern from ECCS (1984). While the initial imperfection is set at 
$1 / 1000$ of the unbraced length which was taken from the study of Avery and Mahendran (2000).

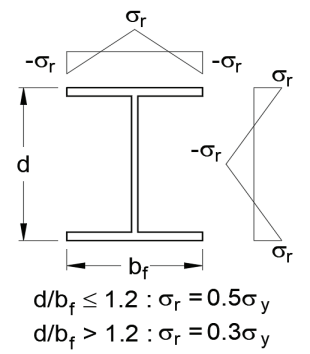

(a) Residual Stress

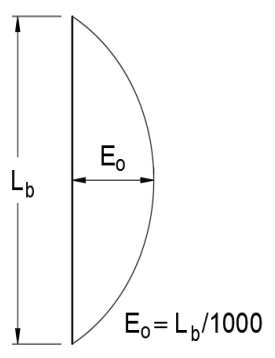

(b) Initial out-of-Straightness
Fig. 6. Initial Imperfections

\subsection{Model Validation}

A comparison between the of the FE analysis and calculated buckling strengths from Eurocode 3 Part 1-2 (2005) were conducted to validate the accuracy of the simulated models. The beams were assumed to be heated throughout the beam (Case F-WB). The results were plotted terms of the reduction factors for lateral-torsional buckling ( $\chi_{L T}$ and $\chi_{L T, f}$ at ambient and elevated temperature, respectively) and different slenderness values $\left(\lambda_{L T}\right.$ and $\lambda_{L, f i}$ at ambient and elevated temperature, respectively).

At ambient temperature, the reduction factor for lateraltorsional buckling $\left(\chi_{L T}\right)$ and the non-dimensional slenderness $\left(\bar{\lambda}_{L T}\right)$ are calculated as

$$
\begin{aligned}
& \chi_{L T}=\frac{M_{b, R d}}{M_{c, R d}} \\
& \bar{\lambda}_{L T}=\sqrt{\frac{W_{p l, y} f_{y}}{M_{c r}}}
\end{aligned}
$$

Where $M_{b, R d}$ is the design buckling resistance moment, $M_{c, R d}$ is the design resistance for bending, $W_{p l y}$ is the plastic section modulus of the cross-section and $M_{c r}$ is the elastic critical moment for lateral-torsional buckling.

At elevated temperature, the reduction factor for lateral torsional buckling in the fire design situation $\left(\chi_{L T f f}\right)$ and the non-dimensional slenderness values $\left(\bar{\lambda}_{L T, f i}\right)$ are

$$
\begin{gathered}
\chi_{L T, f i}=\frac{M_{b, f i, t, R d}}{M_{f i, \theta, R d}} \\
\bar{\lambda}_{L T, f i}=\bar{\lambda}_{L T} \sqrt{\frac{k_{y, \theta}}{k_{E, \theta}}}
\end{gathered}
$$

Where $M_{b_{f} f, t, R d}$ is the design lateral torsional buckling resistance moment and $M_{f, \ell, R d}$ is the fire design moment resistance.

Figs. 7 and 8 illustrate the comparison of results between FE and Eurocode at ambient temperature and elevated temperature, respectively. It can be observed that the simulated models and the calculated strengths from Eurocode behaved similarly with reasonable accuracy. These validate the FE models for investigating the inelastic buckling behavior of steel beams at elevated temperature.

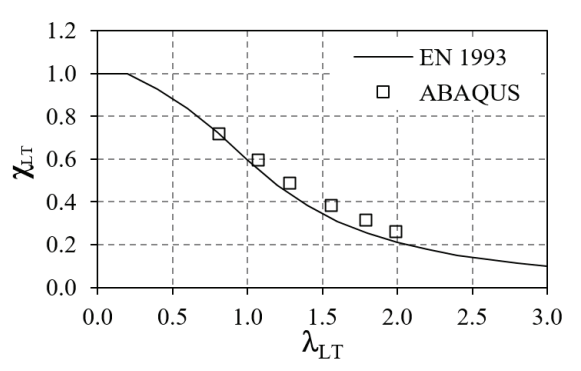

Fig. 7. Comparison of the Numerical and Design Values for $\chi_{L T}$ and $\lambda_{L T}$ at $20{ }^{\circ} \mathrm{C}$

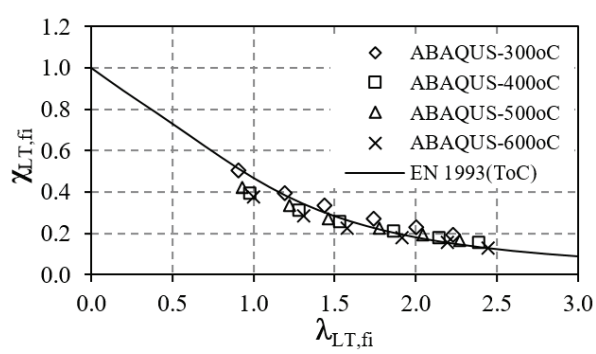

Fig. 8. Comparison of the Numerical and Design Values for $\chi_{L T, f i}$ and $\lambda_{L T, f i}$ at Elevated Temperature

\section{Analysis Results}

\subsection{Critical buckling load}

Geometric and material non-linear analysis with imperfections using shell finite element models were carried out. Eurocode 3 Part 1-6 proposed a method to define the buckling resistance on the load-strain curve shape. According to Eurocode 3 Part 1-6 (2007), a geometric and material non-linear analysis should be performed on the perfect structure to determine the perfect elastic-plastic buckling resistance ratio. The imperfect elastic-plastic buckling resistance should be found as the lowest load obtained from the three following criteria;

- Criterion C1: The maximum load factor on the loaddeformation-curve (limit load); 
- Criterion C2: The bifurcation load factor when this occurs during the loading path prior to reaching the limit point of the load-deformation-curve;

- Criterion C3: The tolerable deformation when this occurs during the loading path prior to reaching a bifurcation load or a limit load.

The load-deformation curves at $20{ }^{\circ} \mathrm{C}$ and $600{ }^{\circ} \mathrm{C}$ at the points T1, T2, T3, B1, B2 and B3 (as shown in Fig. 9) with a length of $7 \mathrm{~m}$ are presented in Figs. 10 and 11 The load-deformation curves are the most similar to the criterion of $\mathrm{Cl}$ which is selected as the critical buckling load.

\subsection{Flexural strength ratio at elevated temperature and buckling mode shape}

Fig. 12 illustrates the reduction ratio of the critical load from the inelastic buckling analysis for the six elevated temperature scenarios. The simulated data were plotted as the ratio of the critical flexural strength at elevated temperature $\left(M_{T^{\circ} \mathrm{C}}\right)$ and at ambient temperature $\left(M_{20^{\circ} \mathrm{C}}\right)$ with respect to the unbraced length.

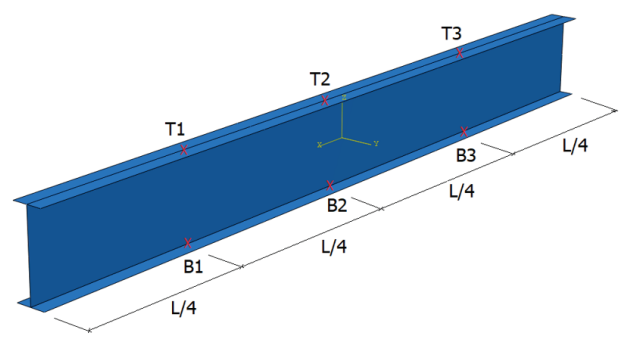

Fig. 9. Points for the Load-deformation Curve

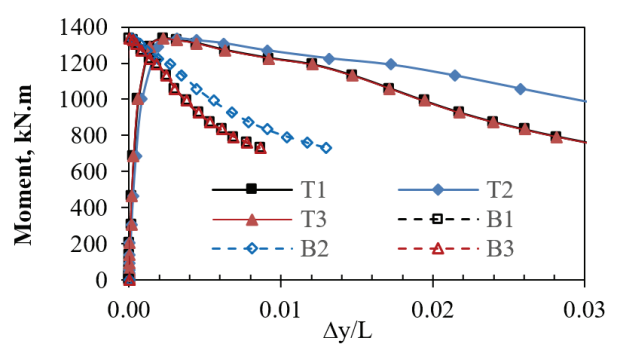

Fig. 10. Load-deformation Curve at $20^{\circ} \mathrm{C}$ with a Length of $7 \mathrm{~m}$

The analyzed beams with a lengths from $5 \mathrm{~m}$ to $18 \mathrm{~m}$ showed variations in the reduction of the flexural strength based on the temperature exposure area. The expected behavior was observed at F-WB, demonstrating fastest decrease in strength when the whole beam is heated. The strength degrades to approximately $52 \%$ to $60 \%$ at $400^{\circ} \mathrm{C}$, and $22 \%$ to $24 \%$

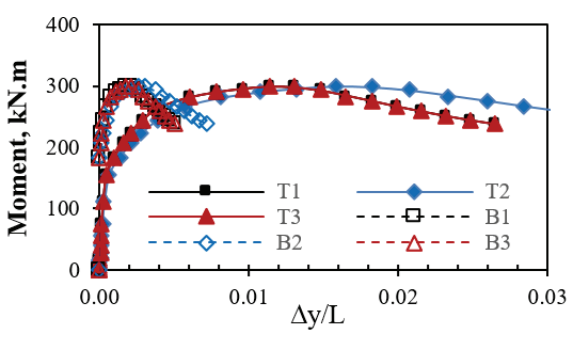

(a) F-WB

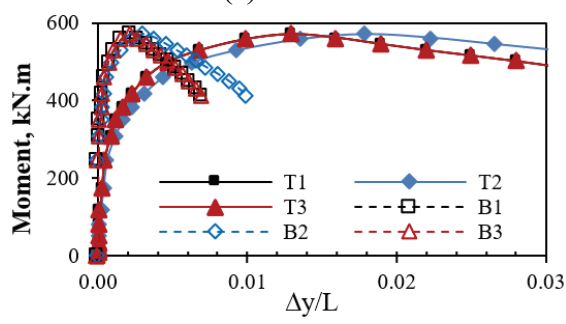

(b) $\mathrm{F}-\mathrm{CF}$

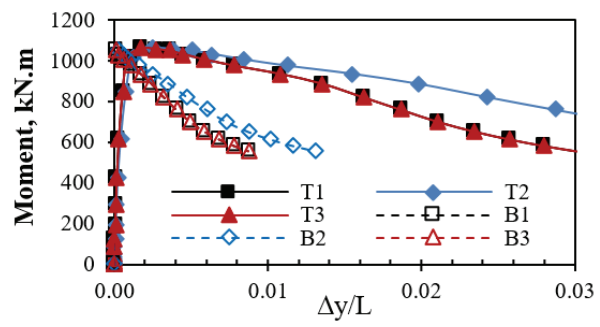

(c) $\mathrm{F}-\mathrm{TF}$

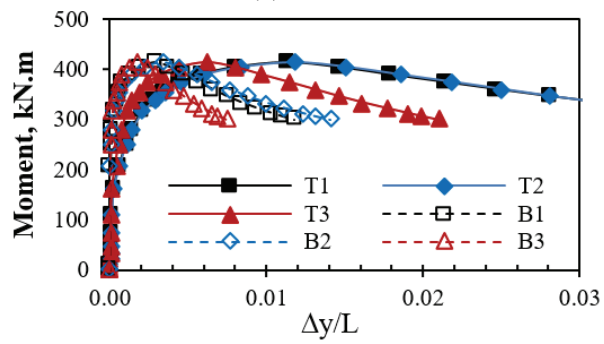

(d) $50 \% \mathrm{~F}-\mathrm{WB}$

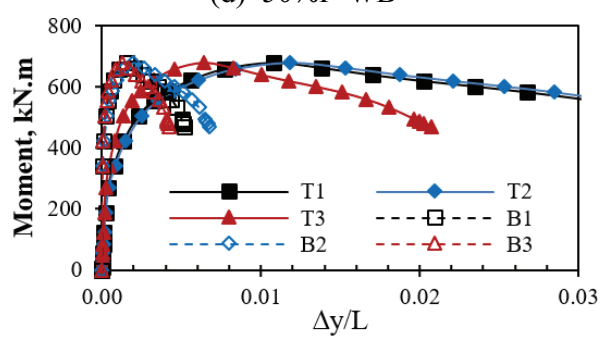

(e) $50 \% \mathrm{~F}-\mathrm{CF}$

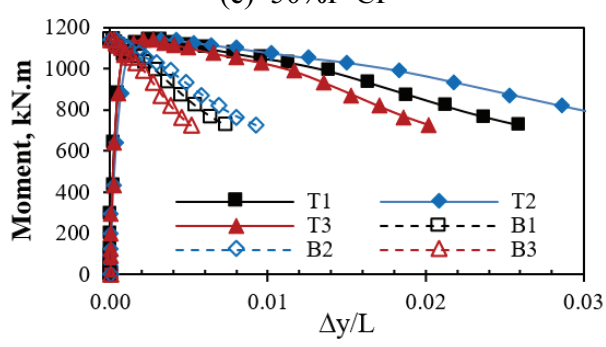

(f) $50 \% \mathrm{~F}-\mathrm{TF}$

Fig. 11. Load-deformation Curve at $600^{\circ} \mathrm{C}$ with a Length of $7 \mathrm{~m}$ in all Cases 


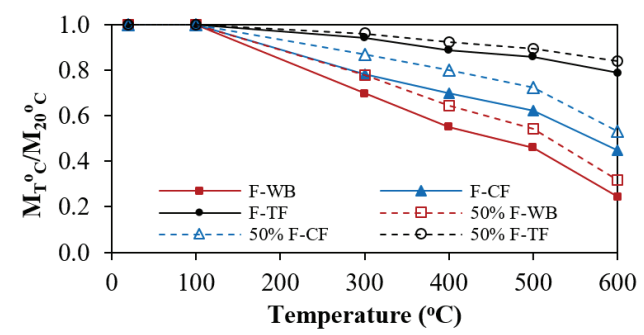

(a) $5 \mathrm{~m}$

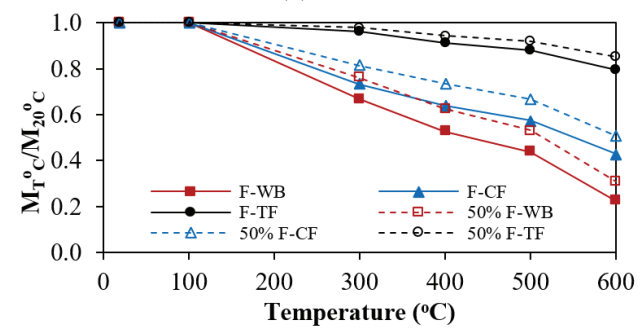

(b) $7 \mathrm{~m}$

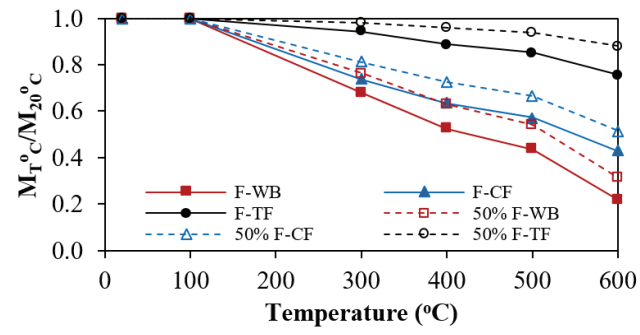

(c) $9 \mathrm{~m}$

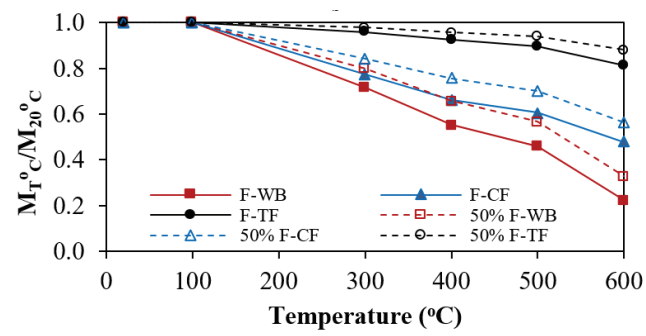

(d) $12 \mathrm{~m}$

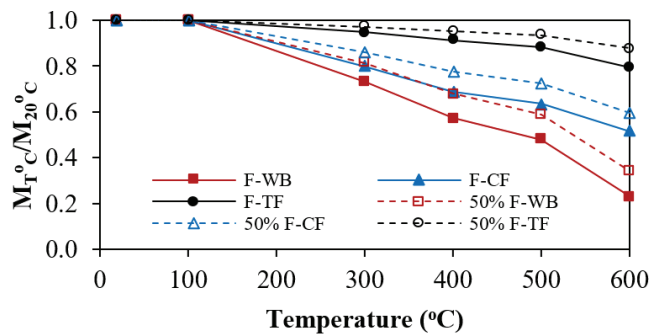

(e) $15 \mathrm{~m}$

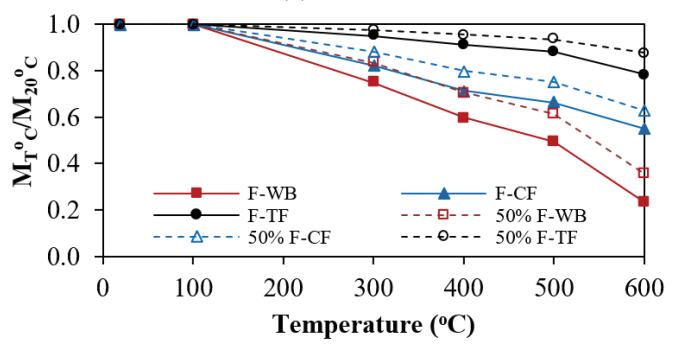

(f) $18 \mathrm{~m}$

Fig. 12. Reduction Ratio in the Inelastic Buckling Strength at $600^{\circ} \mathrm{C}$. While the least critical scenario was observed at case of F-TF and $50 \% \mathrm{~F}-\mathrm{TF}$. At $600^{\circ} \mathrm{C}$, the flexural strength decreased to between $76 \%$ and $81 \%$ for F-TF, and $84 \%$ and $88 \%$ for $50 \% \mathrm{~F}-\mathrm{TF}$.

At $50 \% \mathrm{~F}-\mathrm{WB}$ and $\mathrm{F}-\mathrm{CF}$, the reduction in flexural strength was relatively similar at lower temperature. However, as the temperature exceeds $400^{\circ} \mathrm{C}, 50 \% \mathrm{~F}-\mathrm{WB}$ showed a greater decrease in strength than F-CF. The flexural strength decreased to at least $63 \%$ for both cases at $400^{\circ} \mathrm{C}$. While at $600^{\circ} \mathrm{C}$, the flexural strength was down to approximately $31 \%$ to $36 \%$ for $50 \% \mathrm{~F}-\mathrm{WB}$, and $43 \%$ to $55 \%$ for $\mathrm{F}-\mathrm{CF}$. Lastly, at $50 \% \mathrm{~F}-\mathrm{CF}$, the flexural strength gradually decreased to $73 \%$ to $80 \%$ in strength at $400^{\circ} \mathrm{C}$ and $51 \%$ to $60 \%$ at $600^{\circ} \mathrm{C}$.

The average reduction ratio are summarized in Table 1 For cases of partially elevated temperature in compression components, $\mathrm{F}-\mathrm{CF}$ and $50 \% \mathrm{~F}-\mathrm{CF}$, the reduction in flexural strength was the lowest. At $600^{\circ} \mathrm{C}$, the flexural strength decreased by an average of about $53 \%$ and $44 \%$, respectively. In cases of partially elevated temperature in tension components, $\mathrm{F}-\mathrm{TF}$ and $50 \% \mathrm{~F}-\mathrm{TF}$, the reduction in flexural strength decreased slowly. At $600^{\circ} \mathrm{C}$, the flexural strength decreased by an average of about $21 \%$ and $13 \%$, respectively. In cases of $\mathrm{F}-\mathrm{WB}$ and $50 \% \mathrm{~F}-\mathrm{WB}$, the reduction in flexural buckling strength was the highest. At $600^{\circ} \mathrm{C}$, the flexural strength decreased by an average of about $77 \%$ and $67 \%$, respectively.

Table 1. The Average Reduction Ratio

\begin{tabular}{c|c|c|c|c|c|c}
\hline $\begin{array}{c}\mathrm{T} \\
\left({ }^{\circ} \mathrm{C}\right)\end{array}$ & F-WB & F-CF & F-TF & $\begin{array}{c}50 \% \mathrm{~F}- \\
\text { WB }\end{array}$ & $\begin{array}{c}50 \% \mathrm{~F}- \\
\mathrm{CF}\end{array}$ & $\begin{array}{c}50 \% \mathrm{~F}-\mathrm{T} \\
\mathrm{F}\end{array}$ \\
\hline 300 & 0.71 & 0.77 & 0.95 & 0.79 & 0.85 & 0.97 \\
\hline 400 & 0.55 & 0.67 & 0.91 & 0.66 & 0.77 & 0.95 \\
\hline 500 & 0.46 & 0.61 & 0.88 & 0.56 & 0.70 & 0.93 \\
\hline 600 & 0.23 & 0.47 & 0.79 & 0.33 & 0.56 & 0.87 \\
\hline
\end{tabular}

Figs. 13 and 14 show the inelastic buckling mode shapes of the beam models with unbraced length of $7 \mathrm{~m}$ exposed to temperatures of $300^{\circ} \mathrm{C}$ and $600^{\circ} \mathrm{C}$. The buckling occurred at the center of the beams for F-WB, F-CF, F-TF, and $50 \% \mathrm{~F}-\mathrm{TF}$ illustrating the location of the critical point. In addition, the buckling was observed to occur at the center of the beam at $300^{\circ} \mathrm{C}$ for cases $50 \% \mathrm{~F}-\mathrm{WB}$ and $50 \% \mathrm{~F}-\mathrm{CF}$ but changes the location of the critical point near the heated area at $600^{\circ} \mathrm{C}$. At $300^{\circ} \mathrm{C}$, the yield strength of steel does not change and the elastic modulus decreases to $80 \%$ of its ambient 


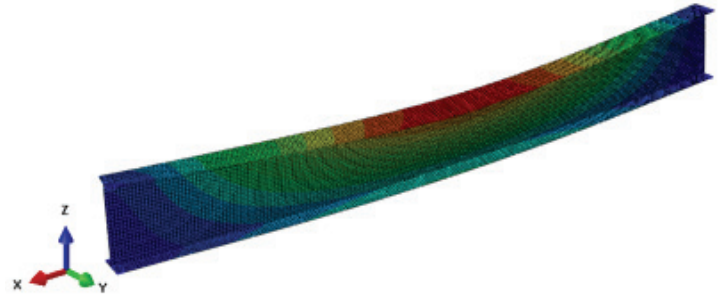

(a) F-WB

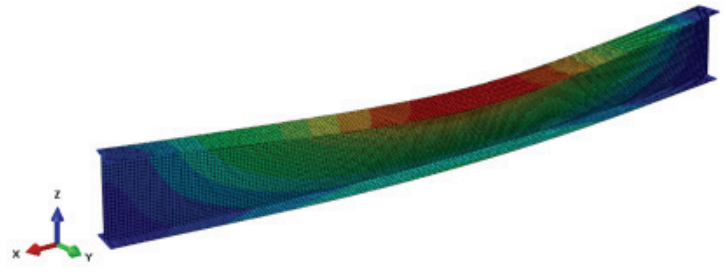

(b) $\mathrm{F}-\mathrm{CF}$

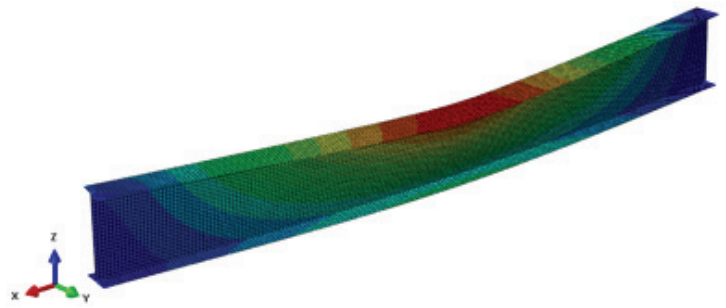

(c) F-TF

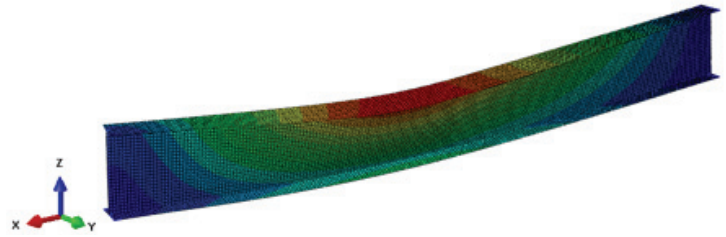

(d) $50 \% \mathrm{~F}-\mathrm{WB}$

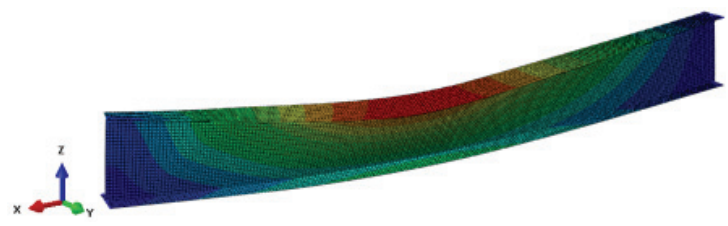

(e) $50 \% \mathrm{~F}-\mathrm{CF}$

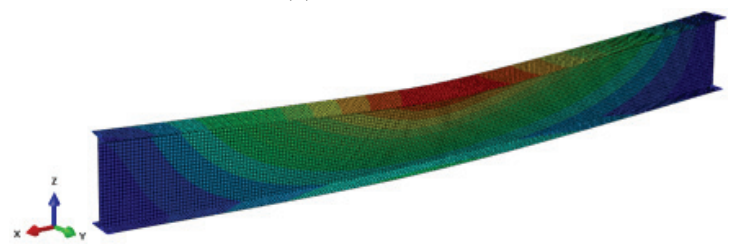

(f) $50 \% \mathrm{~F}-\mathrm{TF}$

Fig. 13. Buckling Mode Shape of the Beam with a Length of $7 \mathrm{~m}$ at $300^{\circ} \mathrm{C}$

temperature values. While at $600^{\circ} \mathrm{C}$, the yield strength decreases about half of its ambient temperature value, and the elastic modulus decreases more rapidly about $30 \%$ of its ambient values. Therefore, at $600^{\circ} \mathrm{C}$ the beam at the heated area will be weaker than the non-heated area of the beam that leads to buckling point near the heated area.

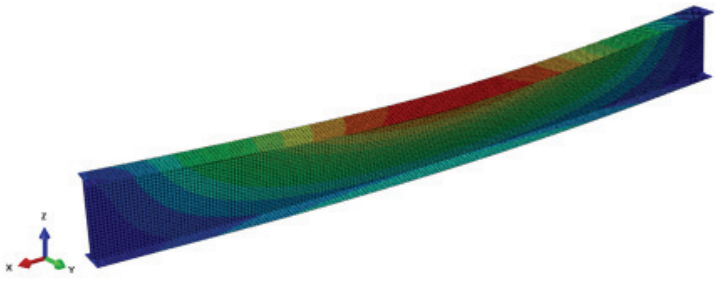

(a) F-WB

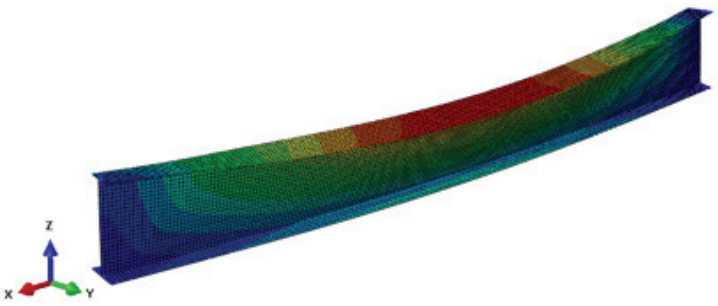

(b) F-CF

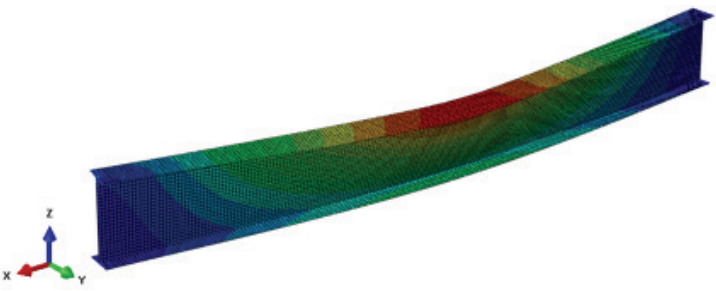

(c) F-TF

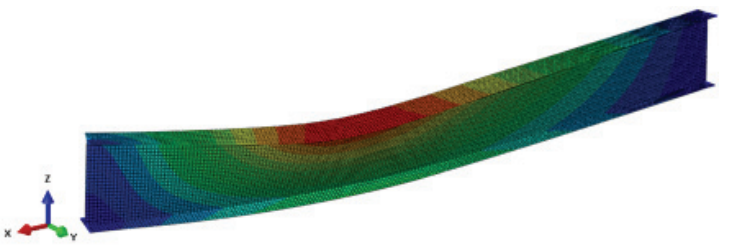

(d) $50 \% \mathrm{~F}-\mathrm{WB}$

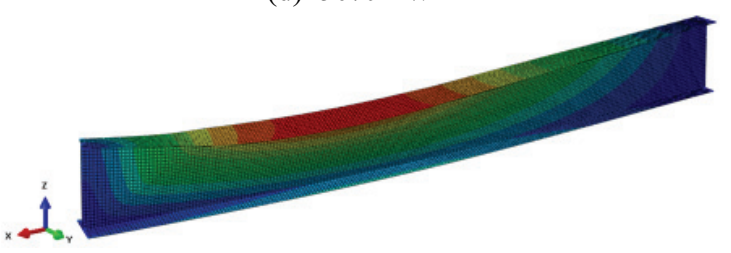

(e) $50 \% \mathrm{~F}-\mathrm{CF}$

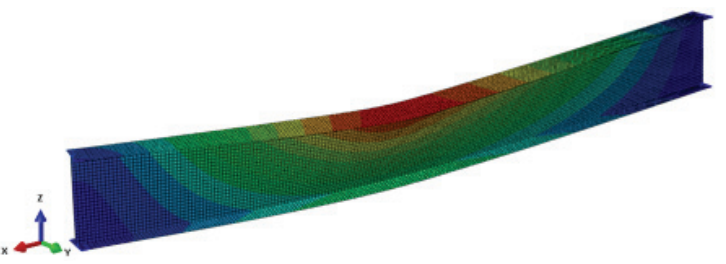

(f) $50 \% \mathrm{~F}-\mathrm{TF}$

Fig. 14. Buckling Mode Shape of the Beam with a Length of $7 \mathrm{~m}$ at $600^{\circ} \mathrm{C}$

\section{Conclusions}

The inelastic buckling behavior of steel beams at elevated was investigated through finite element analysis. According to the results, the flexural strengths of steel beams decreased rapidly when the compression components and the whole 
beam are exposed to elevated temperature. While the tension components gave the least effect on the strength degradation of beams. Therefore, the greater the exposed area of the compression component to elevated temperature, the larger the amount of reduction in flexural buckling strength.

In this study, the elevated temperature was subjected to several parts of the beam such as half and throughout the beam, compression flange, and tension flange. It shows that steel structures are sensitive and vulnerable to elevated temperature that can lead to structural collapse. It is then recommended to investigate the buckling behaviour at elevated temperature and fire resistant performance of steel structures reinforced with protective coating materials.

\section{Acknowledgement}

This research was supported by a 2019 Research Grant from Sangmyung University.

\section{References}

ABAQUS. (2013). Standard user's manual. Version 6.7, Hibbit, Karlsson and Soresen, Inc.

American Institute of Steel Construction (AISC). (2011). Steel construction manual (14th ed). Chicago, IL: AISC, USA.

Avery, P., and Mahendran, M. (2000). Distributed plasticity analysis of steel frame structures comprising noncompact sections. Engineering Structures, Vol. 22, No. 8, pp. 901-919.

Eurocode 3 Part 1-1. (2005). Eurocode 3: Design of steel structures - Part 1-1: General rules and rules for buildings. European Committee for Standardisation (CEN), Brussels, Belgium.

Eurocode 3 Part 1-2. (2005). Eurocode 3: Design of steel structures - Part 1-2: General rules - Structural fire design. European Committee for Standardisation, Brussels, Belgium.
Eurocode 3 Part 1-6. (2007). Eurocode 3: Design of steel structures - Part 1-6: Strength and Stability of Shell Structures. European Committee for Standardisation, Brussels, Belgium.

Couto, C., Real, P.V., Lopes, N., and Zhao, B. (2016). Numerical investigation of the lateral-torsional buckling of beams with slender cross sections for the case of fire. Engineering Structure, Vol. 106, pp. 410-421.

European Convention for Constructional Steelwork (ECCS). (1984). Ultimate limit state calculation of sway frames with rigid joints. Publication No. 33, ECCS-Technical Committee No. 8, Brussels, Belgium.

ISO 834. (1999). Fire resistance tests - Elements of building construction. International Organization for Standardization, Geneva, Switzerland.

Real, P.V., and Franssen, J.M. (2001). Numerical modeling of lateral-torsional buckling of steel I-Beams under fire conditions - Comparison with Eurocode 3. Journal of Fire Protection Engineering, Vol. 11, No. 2, pp. 112-128.

Real, P.V., Lopes, N., da Silva, L.S., and Franssen, J.M. (2008). Lateral - torsional buckling of stainless steel I-beams in case of fire. Journal of Constructional Steel Research, Vol. 64, No. 11, pp. 1302-1309.

Varol, H., and Cashell, K.A. (2017). Numerical modelling of high strength steel beams at elevated temperature. Fire Safety Journal, Vol. 89, pp. 41-50.

Zang, C., Gross, J.L., and McAllister, T.P. (2013). Lateral torsional buckling of steel W-beams subjected to localized fires. Journal of Constructional Steel Research, Vol. 88, pp. 330-338.

\begin{tabular}{|l|l|}
\hline Received & July 5, 2019 \\
\hline Revised & July 9, 2019 \\
\hline Accepted & July 19,2019
\end{tabular}

